\title{
University of Mindanao Assisted Resettlement: A Best Practice in Southeast Asia
}

\author{
Evangeline M. Guinto, Gerlieta S. Ruiz \\ University of Mindanao, Davao City, Philippines \\ Email: evamaguinto@gmail.com, gerlietaruiz@gmail.com
}

Received 7 January 2015; accepted 13 February 2015; published 16 February 2015

Copyright (C 2015 by authors and Scientific Research Publishing Inc.

This work is licensed under the Creative Commons Attribution International License (CC BY).

http://creativecommons.org/licenses/by/4.0/

(c) (i) Open Access

\begin{abstract}
Re-establishing a community-place relationship in a new environment is not easy. First of all, its success has to rely on the determination of the resettlers and external support from the government, academe and other welfare agencies. This study came about to describe the experiences, social support mechanisms and life changes of families resettled to Lubo, Sta. Cruz, Davao del Sur, Philippines in 2004. This study is a qualitative-phenomenological type of research conducted from May to August, 2009. A Focus Group Discussion was conducted for the participants to relate their experiences about resettlement and the key informants' interviews were done for the collateral information. All participants expressed the difficult experience due to poor site selection, hasty decision and lack of consultation among members of the Bugac Maa Urban Poor Settlers Association (BUMUPSAI). Of the 58 resettlement beneficiaries, 18 remained in the site while others returned to Maa for economic reasons. The University of Mindanao and other agencies provided assistance during the relocation. The host community, especially the municipal government of Sta. Cruz, formally accepted them. Since then, the BUMUPSAI has had a regular representative in the Lubo Community Development Council while the municipal government of Sta. Cruz promised to provide the BUMUPSAI basic infrastructures and services needed.
\end{abstract}

\section{Keywords}

Community Extension, Sustainable Development, Social Support Mechanisms, Qualitative Phenomenology, Davao City, Philippines

\section{Introduction}

The world has experienced a phenomenal increase in its landless population and a significant decrease in 
agro-based families over the years, to the detriment of the global economy (UNIDO, 2013). Migration from rural to urban areas is observed not only in industrialized countries but also in third world countries. The reason is not simply because these families want to experience modern life, but because of the hard life caused by lack of employment in the provinces.

Sustainable urbanization is being challenged by unprecedented growth rates. For Reutersward (2008), promoting sustainable urban development is a priority for most urban development advocates as reflected in their policies calling for the joint effort of all stakeholders. Among these stakeholders are the universities around the world which are considered engines for social development. The human material resources of the university are known as prime movers to bridge the gap among education, research and practice in sustainable development.

The Philippine situation is a microcosm of the global experience. The government is not alone in trying to solve the problem of in-migration and its concommitant complex problems such as squatting, congestion and poor living conditions in cities. Non-government organizations, private institutions and universities are also extending a helping hand to mitigate the situation.

The University of Mindanao, through its Community Extension Center (CEC) is one agency which has responded to the plea of the landless urban poor in Maa, Davao City, Philippines, who were about to be evicted. The threat of having no home as a basic sanctuary is a major block to social development and the extension staff of the university did not leave any stone unturned. The CEC staff and social work interns assisted the residents of Maa last May 11-24, 2004, to resettle to Sta. Cruz, Davao del Sur. It was a unique experience where the landowners and the residents conducted negotiations resulting in the resettlement of 58 families from urban to rural area.

This was five years ago. Thus there is a need to revisit the place and reconstruct the experience of those resettled. In a way, this study is also a form of tracing who succeeded and failed in this resettlement.

\section{Framework}

This study is inspired by social change perspectives particularly on Social Solidarity (Crow, 2002). Social solidarity is about how people strive to come together and act as a coherent, unified force. It highlights the importance of establishing social relationships in negotiating with realities. The author shows how social change can be understood in the context of limitations as well as potentialities in the pursuit of solidarity, drawing on social relations in families, communities, universities and many more institutions in society.

This is supported by Adler's concept on social interest as he emphasized that social interest is inherent in every human being. Human beings are social beings and social solidarity espouse that people strive hard to unite with fellows and work together for social perfection (Adler Graduate School, 2014).

Another theory to support social solidarity is Life Trajectories in Changing Societies (Elder, 1994). Interdependence and timing of lives represent key elements of the life course paradigm. People in a community are resources and in a particular point of time in history, they are brought together in one place for them to make connections and contributions for better living. What they do to their new environment is social change and people always find means in creative ways to live comfortable style of life together with others, (Mosak \& Maniacci, 2008).

Studies about life in hard times point out that those who are disadvantaged are not expected to do well in life, yet life trajectories pounded on the contrary. There are a number of disadvantaged people who unexpectedly surmount difficulties and prosper later. He therefore espoused life trajectories as about the capacity of human beings to rise above life's disadvantages, thus, the impact of social change is contingent on the life history people bring to the new situation.

The proponents show that there are people who experienced adversities in life and were at a disadvantaged situation but turned out to be hopeful, self-directed, assertive and confident about the future.

\section{Objectives of the Study}

The primary intention of the study was to describe social change as experienced by resettled families. Specifically, this study aimed to attain the following objectives: 1 ) to describe the resettlement experiences of the participants; 2) to identify social support mechanisms employed by the participants; 3) to describe the life changes experienced by the participants, and 4) to identify the future plans of the resettled families in promoting sustainable development. 


\section{Methodology}

This qualitative study utilizes phenomenology using Focus Group Discussion participated by the resettled families. Key Informant Interviews were also conducted from the government officials of the receiving community, including the representatives from the concerned national government agency and the administrator of the landowner of the departed area (Rubin \& Barbie, 2010).

\section{Results and Discussion}

\subsection{Resettlement Experiences}

All of the participants expressed the harsh life of a hasty relocation. It could not even be accepted as resettlement because by re-settlement we mean that the affected people are now settled. They could have attained a certain degree of comfort or ease in their new dwelling. They were just transported to the host community (Santa Cruz) and it was up to them to adapt to the new environment despite the absence of amenities.

In the second FGD, the twelve families who departed the resettlement area resented the choice of site. Not all of the members were able to visit the site before they were made to decide which one to choose. They claimed that not all the BUMUPSAI members were participative and active during meetings. Their discussions were not very exhaustive that members complained of being pushed to the wall in signing the waiver.

The voluntary nature of resettlement turned out as involuntary as they were pushed to the wall. They had no choice but to sign the waiver or else they would not be relocated but they would be evicted because they do not own the land.

\subsection{Social Support Mechanisms}

The participants recognized agencies that provided assistance to this relocation such as the local government unit of Davao City, the Philippine Commission of the Urban Poor (PCUP), the University of Mindanao Community Extension Office and the municipal government of Sta. Cruz, Davao del Sur.

Academic institutions play a vital role in sustainable development (Reutersward, 2008) and this is articulated in the vision and mission of the University of Mindanao. The trilogy of instruction, research and extension is strongly advocated thus, the University of Mindanao, through the students of the Social Work program assisted in the facilitation and documentation of the relocation activity. This included follow up assistance with the City Planning \& Development Office, the City Engineer's Office and the preparation of the Memorandum of Understanding with the land-owner and the community.

On the other hand, FGD participants stressed that being a member of the BUMUPSAI was beneficial to them. From this association, they gathered strength in negotiating with the landowner, networked with agencies for possible assistance and got social support. The BUMUPSAI officers did the initiating and maintaining tasks to sustain the association (Bartle, 2009). However, attendance problem during meetings and the diminishing attachment to the group need to be properly addressed, so that this will not result in disengagement or eventually in losing ownership of the resettlement area which was supposed to be theirs.

The participants appreciated the host community, the Barangay Development Council (BDC) and the municipal government which demonstrated genuine openness and acceptance to the resettlers. But in the long run, they also recognized the need to re-examine the extent of assistance they would be getting from the government. They also realized that assistance provided by support agencies to the BUMUPSAI have not been sustained. They admit that the more challenging one is the recalibration and revitalization of their organization and nobody takes this role except the leaders. They should not rely on external support but more on their own capacity for sustainability.

\subsection{Life Changes after the Resettlement}

Those with good working habits and dedication to improve livelihood were able to succeed. Despite the lack of amenities in the resettlement area, there were 18 families who decided to stay in the resettlement until the time of this study. They were able to integrate with the host community and their leaders regularly sit as members of the BDC.

Whereas, those failed settlers did not seem to participate in the program due to greater expectations of the re- 
settlement area. They relied on luck and look forward to owning the Promised Land and to be provided with good infrastructure and services. Their expectations were not met and their source of livelihood is in Davao City so they departed and regrouped with kins and friends in the city.

For those who returned to the city, they said "life remains the same”. Still, they don't own the land but they chose to live the way they did before and they hold on to their ownership of that resettlement area in Sta. Cruz, Davao del Sur. They hope that someday they can finally settle in that place. Among the Filipino urban poor they might be stigmatized as "professional squatters" because they could be interpreted as "opportunist". They aspire to have a land of their own but once given to them, they will depart the place and join another group of informal settlers (Tebbal \& Ray, 2009). They may have ignored the label given to them in exchange of the comfort they derive from reuniting with kins, relatives and close friends. These are ties which are sources of nurturance and sustenance as people and they go back to where they can satisfy their belonging needs.

Economically, it is too early to say that there is a significant change in the lives of the resettled families. There is a need to re-investigate through further research. In the first place, there were no inputs or livelihood assistance yet; if ever there are improvements in their lives, these are through personal efforts.

Politically, a BUMUPSAI leader sits as a regular member of the Barangay Development Council (BDC) but as to how influential they are in the decision making process is another interesting topic. They are represented in the BDC but within their organization, they are in crisis because some of their members departed the resettlement and returned to the city.

Culturally, they are able to integrate with the host community and they are able to transfer their technology of organizing to the receiving community and the BDC. There are no problems about competing for resources in the resettlement site because they have accepted the fact that resources are really scarce. What they are requesting for is only a multi-purpose center for their meetings and that is not as vital as the need for water and access roads.

\subsection{Future Plans toward Sustainable Resettlement}

Despite geographical division, those in the resettlement area and those in the city, BUMUPSAI continue to exist as one association under one president.

The participants recognized that they need to re-accredit their association and comply with the Securities and Exchange Commission requirements. More than legalities, they need to rejuvenate their members for more effective reforms in the organization. They also need to strengthen their network with other agencies for social welfare services. Most of all, they must coordinate with the municipal government of Sta. Cruz for upgrading of the resettlement area. They can get the support of the host community or the original residents in the barangay because they have the same need (Bartle, 2009) and with one solid voice, they can mobilize the municipal government to attend to their urgent needs.

They urged those who returned to the city to finally resettle in Sta. Cruz. They would be more empowered if they are united. However, those in the city are also waiting for the provision of basic necessities before they can be enticed to return to the resettlement site. The cycle goes on, should they resettle first and lobby for improvements or wait for improvements before they resettle?

Lastly, the participants especially the officers admit that they need a comprehensive program. Experts in resettlement agree that without a comprehensive program package we can never expect resettled families to attain better lives. Time and again the government officials have to equip themselves if they are serious in providing quality life for our people. Foremost is the provision of gainful employment and the basic necessities in the community.

\subsection{Summary}

1) It is too early to say that there is a significant change in the economic lives of the people. There is a need to take a deeper investigation on this issue. In the first place, there were no inputs or livelihood assistance yet so if ever there are improvements in their lives that could be attributed to their personal efforts.

2) Kinship and solidarity continue to influence the relocatees' choice of domicile. They ignore the stigma as professional squatters in exchange of the comfort they derive from reuniting with kins, relatives and close friends. These are ties which are sources of nurturance and sustenance as a people and they go back to where they have satisfied the belonging they need. 
3) Problems are inevitable in any relocation site, but community problems as experienced by the relocatees served as opportunities for their organization to rebuild trust within them and act together for transformation, liberation and self-reliance. There locates realize it is now in their hands how they can work together for their own interest to solve these problems collectively, (Konta, 2007; Bartle, 2009).

4) Social support mechanisms play a big role in enabling people to adjust to a new life in the relocation areas. Government agencies, NGOs and the academe are resources that could provide support but the main actors in community life are the people themselves. BUMUPSAI as a genuine people's organization musters strength from its members and these are the resources within, whereas partner agencies are external resources that can support to hasten the social change that BUMUPSAI has initiated.

\section{Conclusion}

BUMUPSAI leaders who are hopeful and confident of the future are playing dual role as community leaders and as organizers. They have demonstrated a great deal of strength despite uncertainties to transform their organization from landlessness to owning a piece of land (Konta, 2007). They learned from their struggle, from powerlessness they learned to bond and take action.

People in a community are resources and in a particular point of time in history, they are brought together in one place for them to make connections and contributions for better living. What they do to their new environment is social change and people always find means in creative ways to live comfortable style of life together with others, (Adler Graduate School, 2014; Elder Jr., 1994).

The interconnectedness of economic, political and socio-cultural development in the community is concretized in this resettlement program. There are people who show determination despite uncertainties. They are those who have positive attitude for finding livelihood in new environment, value hard work complemented by their confidence and fullness of hope amidst hardships. That led them to economic improvement. People who moved on are those who face the future with confidence thus, most likely are determined to succeed while those who back track can never move on and most likely doomed to fail (Elder Jr., 1994).

Also emphasized from the experience are the self-directed and self-governed virtues of people for a dynamic political life. They moved together to a new environment and to be able to survive, they have governed themselves. Lastly, the resettlement experience stressed integration of resettlers with the host community for social development to occur.

Social solidarity, social interest, coupled with enriched network and linkages with the university as engine for development, the municipal government and non-government entities facilitated people's empowerment. In other words, the balanced interplay of people in the community as social beings redounds to sustainable development. More than anything else, it is the people who are decisive. The main actors were the resettlers who made the necessary adjustments and immersed themselves in a new community. Thus, sustainable development can only happen if people decide to work in solidarity with others to let it happen (Crow, 2002).

\section{References}

Adler Graduate School (2014). Alfred Adler: Theory and Application. http://www.alfredadler.edu/about/theory

Bartle, P. (2009). Community Organization. http://www.scn.org/cmp/modules/mnt-org.htm

Crow, G. (2002). Social Solidarities. http://ww.mcgraw-hill.co.uk/openup/chapters/0335202306.pdf

Elder, G. H. (1994). Life Trajectories in Changing Societies. Self-Efficacy in Changing Societies, 46-68. http://www.google.com.ph/books?hl=en\&lr=\&id=JbJnOAoLMNEC\&oi=fnd\&pg=PA46\&dq=Life+Trajectories+by+Elder\&ots http://dx.doi.org/10.1017/CBO9780511527692.004

Konta, S. (2007). Community Organizing: Citizens Working Together to Transform Their Communities. http://www.community-organizing-a25216.htm.

Mosak, H. H., \& Maniacci, M. (2008). Current Psychotherapies. 69. http://www.google.com.ph/books?hl=en\&lr=\&id=67yuMhJ5ieQC\&oi=fnd\&pg=PA67\&dq=related:bjKs5OcQJBsJ:schola r.google.com/\&ots

Reutersward, L. (2008). UN Habitat II Proceedings. http://www.unhabitat.org/categories.asp?catid=570

Rubin \& Babbie (2010). Essential Research for Social Work. USA: Brook/Cole Cencage Learning.

Tebbal \& Ray (2009). Housing the Urban Poor: Lessons Learned. 
http://scholar.google.com.ph/scholar?hl=tl\&lr=\&q=related:tqFZZb05cOgJ:scholar.google.com

UNIDO (2013). Accelerated Agribusiness and Agro-Industrial Development Institution.

http://www.unido.org/fileadmin/user_media_upgrade/What_we_do/Topics/Agribusiness_and_rural/UNIDO_Agribusiness development.pdf 
Scientific Research Publishing (SCIRP) is one of the largest Open Access journal publishers. It is currently publishing more than 200 open access, online, peer-reviewed journals covering a wide range of academic disciplines. SCIRP serves the worldwide academic communities and contributes to the progress and application of science with its publication.

Other selected journals from SCIRP are listed as below. Submit your manuscript to us via either submit@scirp.org or Online Submission Portal.
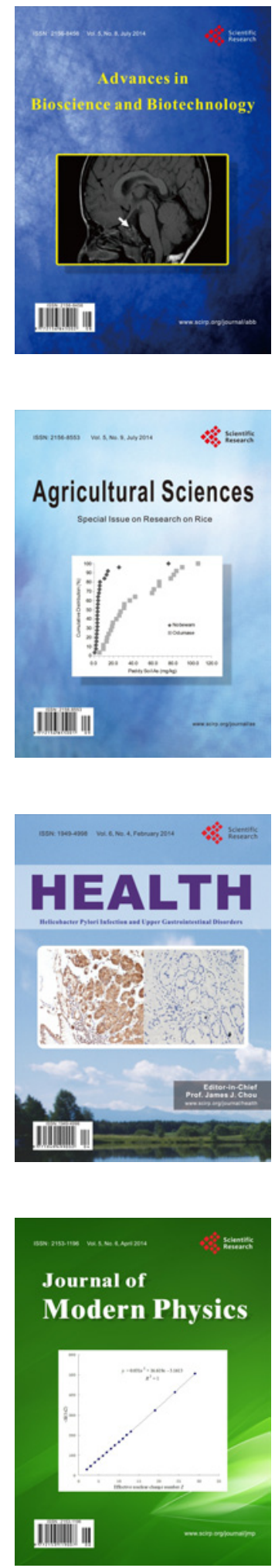
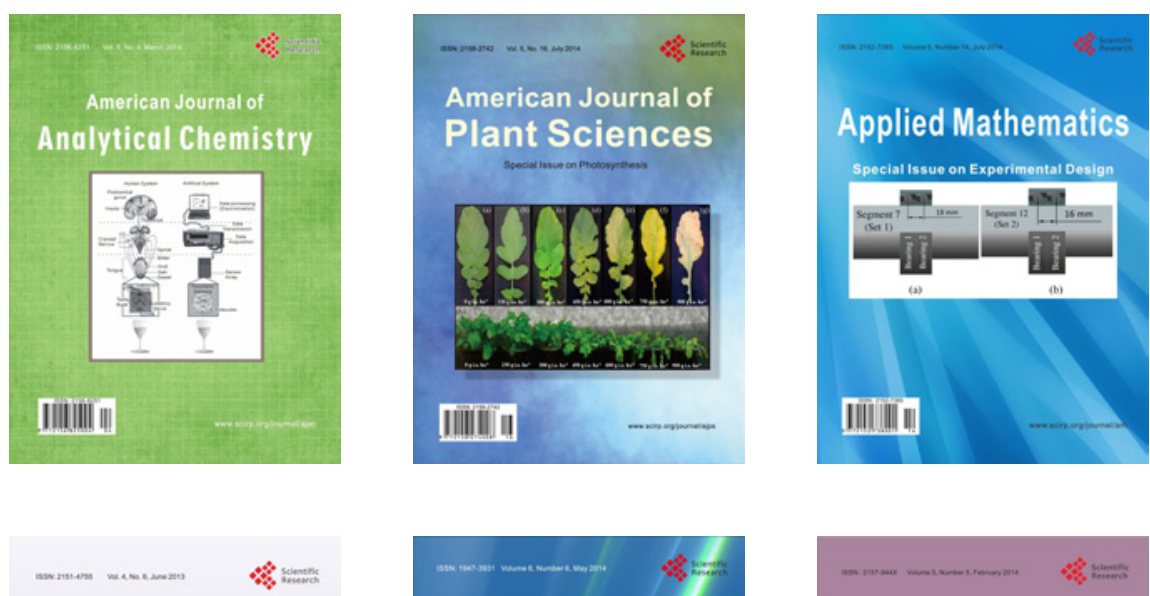

Creative Education
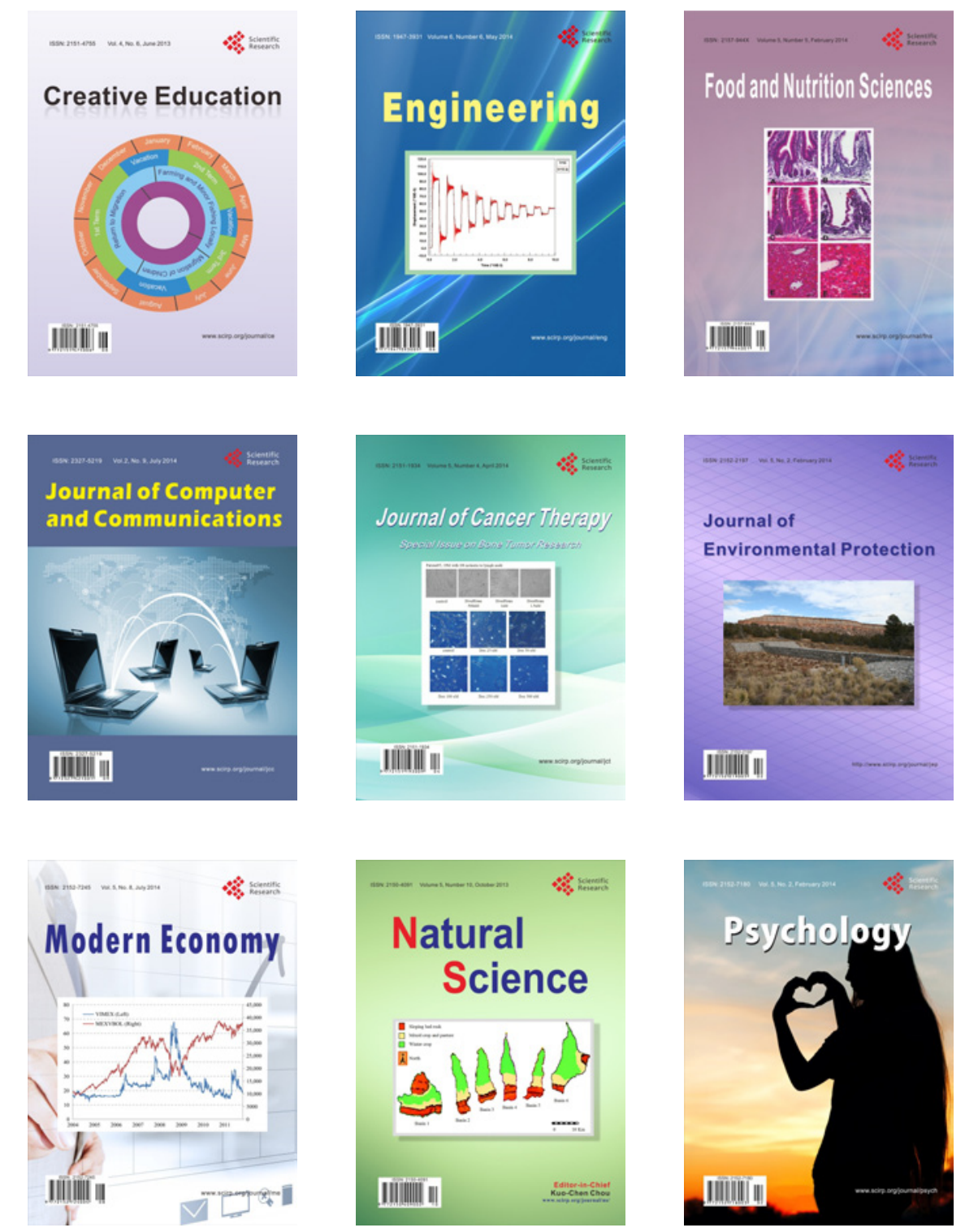